\title{
Endoscopic Endonasal Skull Base Repair with Nasoseptal Flap
}

\author{
Kun Hee Lee and Chul Won Yang \\ Department of Otorhinolaryngology-Head and Neck Surgery, Kyung Hee University Hospital at Gangdong, Seoul, Korea
}

\section{비중격피판을 이용한 두개저 재건}

\author{
이 건 희·양 철 원 \\ 강동경희대학교병원 이비인후과
}

\author{
Received April 4, 2014 \\ Accepted June 29, 2014 \\ Address for correspondence \\ Kun Hee Lee, MD \\ Department of Otorhinolaryngology- \\ Head and Neck Surgery, \\ Kyung Hee University \\ Hospital at Gangdong, \\ 892 Dongnam-ro, Gangdong-gu, \\ Seoul 134-727, Korea \\ Tel $+82-2-440-6181$ \\ Fax $+82-2-440-7336$ \\ E-mail nose4U@gmail.com
}

Endoscopic endonasal approach (EEA) for the skull base surgery has been widely accepted since the advent of image guidance system and new reconstruction method. EEA has the advantage of being non-invasive approach with low morbidity. Among many reconstructive methods nasoseptal flap is the method of choice because of the proximity to the skull base and hypervascularity as a pedicled flap. In this review, the authors introduce the indication, surgical techniques and postoperative complications of nasoseptal flap.

Korean J Otorhinolaryngol-Head Neck Surg 2015;58(1):7-11

Key Words Endoscopic endonasal approach · Nasoseptal flap · Skull base reconstruction.

\section{서 론}

내시경의 출현으로 부비동 수술의 획기적 발전을 가져온 이 래 영상유도시스템(image guidance system)과 미세수술기구 의 개발로 부비동을 넘어서 두개저 외상이나 종양의 수술적 접 근 및 재건을 위한 기술이 비약적으로 발전해왔다.

신경외과와 협동수술을 하게 되지만 적절한 이비인후과 수 술 처치명이 없는 국내와 달리 외국에서 두개저 재건은 이비인 후과의사에게 새로운 수술 영역으로 자리잡았다. 결국 재건 술의 발전이 보다 더 광범위한 수술이 가능하게 한 원동력이 되었다고 해도 과언이 아니다. 내시경비내접근법(endoscopic endonasal approach, EEA)을 통한 두개저 결손의 재건을 위 해 여러 가지 자가이식 조직과 부수적인 인공재료들이 사용되 었다. 자가이식 조직 중 대표적으로 측두두정 근막(temporoparietal fascia), 두개골막(pericranial fascia), 두개골건막(galeopericranial fascia) 등이 소개되었다. 하지만 이는 외부의 추가 절개를 통해서만 피판 획득이 가능하다는 단점이 있다. 이
로 인해 같은 내시경 시야에서 이용할 수 있는 비중격 피판(nasoseptal flap)을 이용한 재건술이 2006년 시도되었으며 수술 후 뇌척수액 유출을 50\%에서 5\% 이하로 줄일 수 있었다. ${ }^{1)}$ 이 는 접형구개동맥(sphenopalatine artery)의 후방분지로부터 혈 액 공급을 받고 재건을 위한 충분한 길이, 너비를 가지며 회전 이 가능한 장점에 의한다고 하였다. ${ }^{1)}$

저자들은 이비인후과의사에게 친숙한 비중격을 이용한 재 건의 기본적인 적응증과 방법에 대해 알아보고 이를 토대로 $\mathrm{EEA}$ 에서 이비인후과의사의 역할에 대해 생각해보고자 한다.

\section{본 론}

\section{적응증}

비중격 피판은 두개저 수술 후 발생한 결손의 여러 겹 재건 을 위한 유용한 재료이며 광범위한 뇌경막 절제가 요구되는 수 막종(meningioma)이나 두개인두종(craniopharyngioma), 크 기가 큰 뇌하수체 선종과 같은 수술 후 재건으로 사용될 수가 
있다. 비중격 피판은 $\mathrm{Hirsch}^{2}$ 에 의해 1952년 처음 뇌하수체 유 출을 막는 데 사용되었으며 비중격 피판 중에서도 Hadad-Bassagasteguy flap이 가장 선호되고 있다.1) 이는 왕성한 혈관분 포와 넓은 면적을 가지고 있어 큰 두개저 결손에도 유용하게 사용할 수 있는 장점을 가지고 있기 때문이다. ${ }^{34)}$ 비중격 피판 은 비중격의 연골막, 골막을 포함하며 접형구개동맥의 분지로 부터 혈액 공급을 받는 피판이다(Fig. 1). 비중격의 연골막과 골막은 내측의 연골 혹은 비골에 밀착되어 있는데 혈관은 점 막하에 위치하므로 피판은 연골막까지 포함하여 깊게 형성되 어야 하는 것이 비중격 피판의 특징이며 이로 인해 여러 겹의 두개저 재건이 가능할 수 있다. ${ }^{4}$ 또한 비중격 피판은 술 후 방 사선치료가 요구되는 환자의 경우에도 좋은 혈관분포로 인해 방사선치료 후 합병증을 최소화할 수 있는 장점을 가지고 있다.

최근에 발표된 문헌고찰에서도 낮은 유속의 뇌척수액 유출 [low-flow cerebrospinal fluid(CSF) leak]의 경우에는 여러 겹의 유리이식(multi-layer free grafts)과 혈관경판(vascularized flap)의 성공률이 차이가 없지만 높은 유속의 뇌척수액 유출(high-flow CSF leak)의 경우에는 혈관경판의 성공률이 더 우월한 것으로 보고되었다. ${ }^{5)}$ 뇌척수액유출의 낮은 유속과 높은 유속을 규정짓는 절대적인 기준이 있지는 않지만 대개 거 미막(arachnoid membrane)과 뇌수조(brain cistern)나 뇌실 (ventricle)이 연결되면 높은 유속의 유출로 간주된다.

뇌척수액유출의 유속과 함께 결손의 위치도 재건의 방법을 결정하는 인자로 생각되는데 사대결손(clivus defect)에는 75 $100 \%$ 의 성공률로 비혈관판(non-vascularized flap)의 $60 \%$ 보다 우월했다. 하지만 전방두개저(anterior cranial base), 터 키안(sella), 결절(tuberculum) 부위에서는 차이가 없었다.) 또

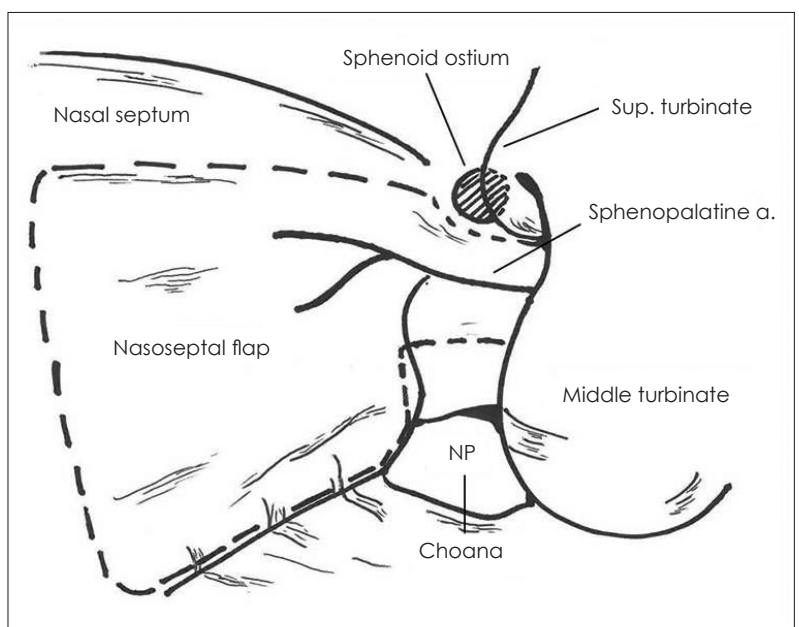

Fig. 1. The schematic view of Lt nasoseptal flap. Upper incision is made at the lower margin of sphenoid ostium. Lower incision is made at the lower end of the septum. The flap is supplied by the posterior septal branch of the sphenopalatine artery. NP: nasopharynx.
다른 장점은 비중격 피판은 여러 번 사용할 수 있다는 것이다. 종양 재발 등에 의해 재수술이 필요한 경우 전에 유치했던 피 판을 떼어낸 후 다시 사용할 수 있다.

요약하면 큰 결손이나 높은 유속의 뇌척수액 유출, 사대결 손, 수술 후 방사선 치료가 계획되어 있는 경우가 좋은 적응이 될 수 있겠다.

\section{수술 과정}

\section{수술 준비}

대개 신경외과의 한 명, 이비인후과의 한 명, 즉 두 명의 집 도의가 네 개의 손을 쓰는 이른바 two-surgeon, four-hand technique이 많은 이점이 있다. 특히 내시경이 익숙하지 않은 신 경외과의의 경우 별도의 보조인력으로 하여금 내시경을 들게 하더라도 이비인후과의가 들고 보여주는 내시경 시야와는 많 은 차이를 보인다. 따라서 병변 제거시에는 이비인후과의가 내 시경을 들어주고 피판을 얻을 때와 유치시킬 때에는 신경외과 의가 바뀌서 들어주는 것이 수술을 효율적으로 할 수 있게 만 들어준다. 전신 마취하에 수술이 진행되며 일반적인 터키안을 통한 접근법(transsellar approach)의 경우에는 환자의 위치 는 바닥에 평행하게 취하지만 두개저 전방으로의 접근을 용이 하게 하기 위해서는 약간의 목을 젖힌 자세(head extended position)가 도움이 된다. 반대로 사대와 치아돌기 부근(odontoid region)의 수술적 접근을 위해서는 약간의 목을 꺾은 자세(head flexed position)가 적합하다. ${ }^{6}$

복부지방과 대퇴근막(fascia lata)을 채취할 경우에 대비해 수술부위를 준비해 놓는다. ${ }^{7.8}$

\section{피판 들어올리기}

예상되는 결손의 크기 및 모양에 따라 피판의 크기와 절개 연 등을 미리 결정한 후 디자인한다. 절개를 하기 전 비중격골 극(bony spur)이나 연골부 만곡(cartilaginous deviation)의 유 무, 불규칙한 점막(mucosal irregularity) 등과 같은 피판이 찢 어질 만한 요소가 없는지 파악하는 것도 중요하다.10) 한쪽 면 의 피판만 필요한 경우 비중격 만곡 등의 문제가 없다면 대개 좌측에서 얻게 되는데 수술자가 환자의 우측에 위치해서 채 취하는 게 더 편리하다. 수술시에 수술자가 주로 사용하는 우 측 손이 좌측 비공으로 빈번하게 출입하게 되므로 채취한 후 비인두 혹은 middle meatal antrostomy(MMA)를 한다면 상 악동 안에 위치시켜 혈관이 다치지 않도록 조심해야 한다.

우선 접형동 자연공을 확인하기 위해 중비갑개와 상비갑개 를 외향골절시켜 준다. 중비갑개뿐 아니라 상비갑개를 함께 골 절시켜야만 보다 더 넓은 시야를 확보할 수 있다. 일부 술자들 
은 중비갑개를 절제하여 시야도 확보하고 중비갑개 점막은 피 판을 들어올린 후 비중격의 노출된 뼈나 연골을 덮어주는 용 도로 쓰게 되는데 점막 재생을 도울 수 있는 좋은 방법이라고 생각된다. 내시경수술에서 흔히 하게 되는 접형구개신경절(sphenopalatine ganglion)의 국소 에피네프린 주사는 피판경의 혈관분포를 손상할 우려가 있으므로 시행하지 않는 것이 원 칙이다. 피판의 절개는 Bovie나 cold knife를 이용할 수 있는 데 bovie는 절개과정에서 출혈이 많지 않은 장점을 가지지만 cold knife가 열로 인한 점막조직의 손상을 줄여 공여 비중격 의 재점막화에 우월한 이점이 있다. Bovie를 이용하는 경우 발 생되는 연기를 없애기 위해 피판을 채취하는 반대편 코에 suction tube를 넣어 위치시키면 시야에 도움이 된다.

첫 번째 절개는 접형동 자연공의 하연에서 시작하게 되는 데 중비갑개의 전방부까지 절개를 시행한 후 전상방으로 꺾어 서 절개를 한다(Fig. 2). 상방 절개시 주의할 점은 후상방에 위치한 후각신경점막을 최대한 보존하기 위해 후상방 쪽에서 $1 \mathrm{~cm}$ 정도 경계를 두고 절개를 한다. 이어 수직 절개를 한 후 비강저와 비중격 사이에 대개 뒤쪽으로 절개를 하게 되는데 큰 피판을 필요로 할 때에는 비강저를 더 많이 포함하여 절개 를 한다(Fig. 3). 앞쪽에서부터 피판을 들어 후비공까지 도달 한 후 후비공 상연을 따라서 절개를 해야 피판의 장력을 줄일 수 있다.
피판의 유치(Flap positioning)

가장 주의 깊게 고려해야 하는 사항은 피판이 위치할 부위 에 결손부위 주위 점막을 충분히 제거하는 것이다. 점막이 남 아 있으면 향후 점액낭종이 생기거나 피판과 뼈 사이에 사강 (dead space)이 생겨 피판이 벌어지게 된다.

어떤 재료를 사용하던 봉박이이식(inlay graft) 혹은 중첩이 식(onlay graft)이 끝난 후 비중격 피판을 유치하게 되는데 피 판이 말려서 혈관경이 손상되지 않도록 하며 써지셀을 이용하 여 피판의 경계부위를 눌러준다. 이어서 젤폼을 이용하여 전체 적으로 피판을 눌러준다(Fig. 4). 섬유소 아교(fibrin glue)의

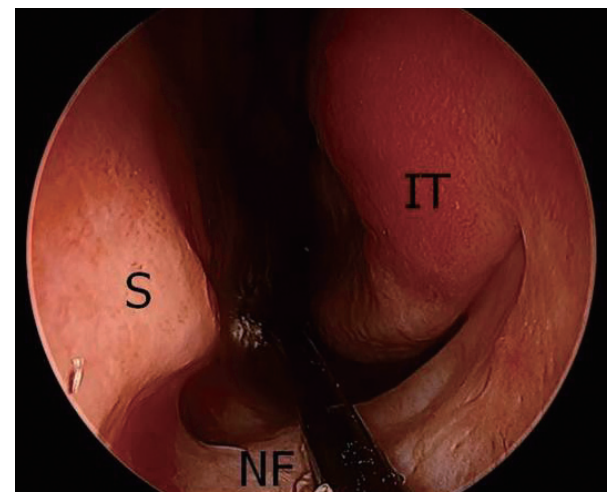

Fig. 3. The next incision is made at the lowest margin of nasal septum but nasal floor is often included to make a bigger flap. S: septum, NF: nasal floor, IT: inferior turbinate.
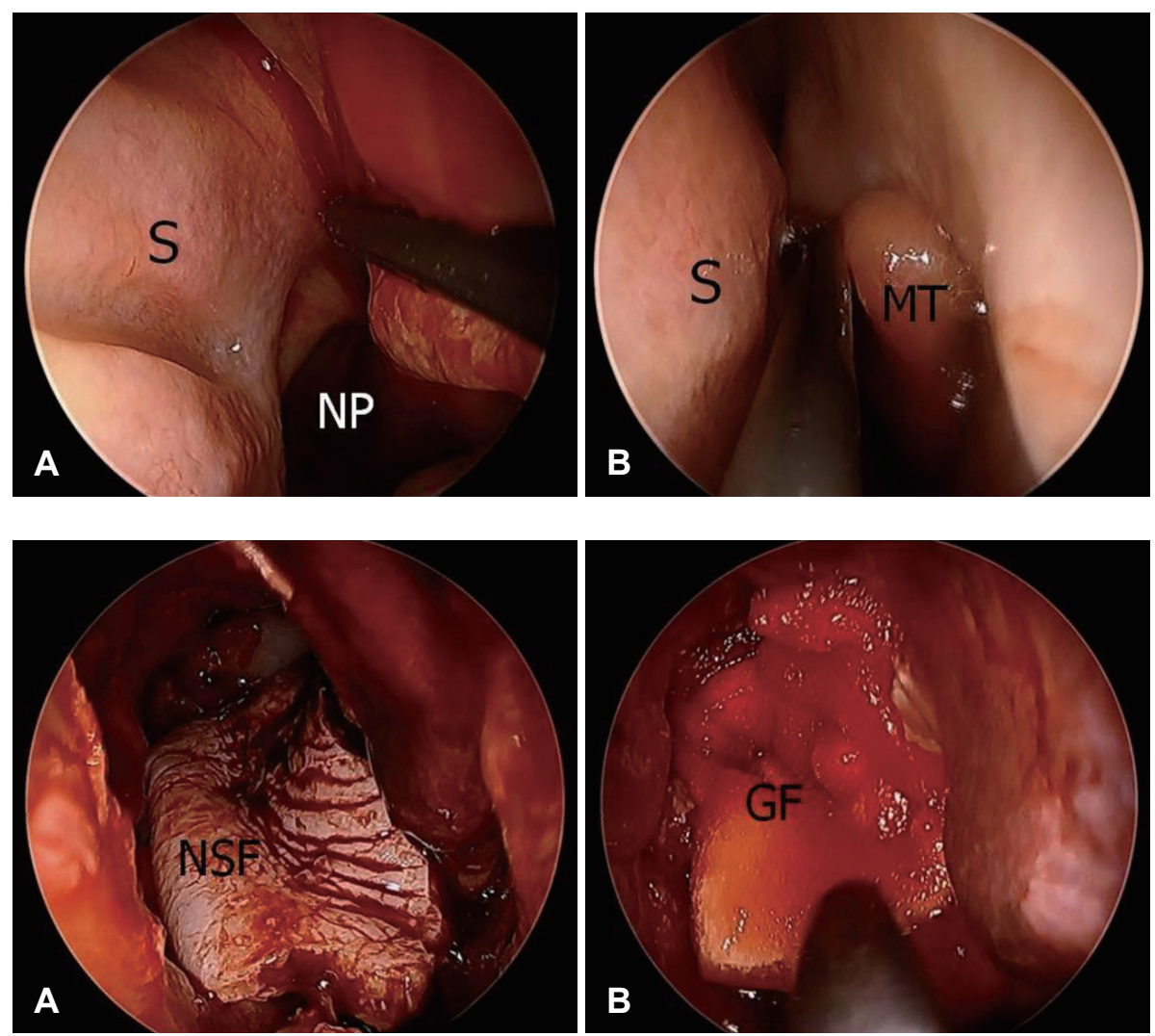

Fig. 2. First incision is made at the lower margin of sphenoid ostium (A). And it continues to the middle one third of the middle turbinate and extends anterosuperiorly (B). S: septum, NP: nasopharynx, MT: middle turbinate.

Fig. 4. When positiong the flap to the skull base defect you shoud avoid kinking of the flap to preserve vascularity (A). Gelfoam is packed after placing the flap (B). NSF: nasoseptal flap, GF: gelfoam. 
무조건적 사용에 대해서는 수술 후 뇌척수액 유출 방지에 유 의한 도움이 되지 않고 오히려 사강을 늘릴 수 있다는 주장도 있으므로 생각해봐야 한다.') 마지막으로 메로셀이나 폴리카테 터를 이용해 패킹을 하게 되는데 둥근 카테터보다는 메로셀 이 골고루 눌러주는 효과는 우월할 것으로 생각된다(Fig. 4). 하지만 지나친 압박은 혈관 장애를 일으킬 수 있으므로 주의 한다. 비중격에는 실리콘시트를 넣고 2 3주간 유치하게 된다.

\section{수술 후 관리}

수술 후 일반적으로 발생할 수 있는 합병증은 두개저 결손 의 완벽한 재건이 이뤄지지 않았거나, 추가적인 작은 결손의 발생으로 인한 뇌척수액 누공의 형성을 들 수가 있다. 이를 방 지하기 위해 환자로 하여금 코를 풀지 않게 하며 재채기를 할 때에도 입을 막지 않게 유도하는 것이 중요하며 뇌압을 상승시 키는 무리한 활동을 자제하도록 하여야 한다. 변비 또한 뇌압 상승의 주요한 원인이 될 수 있으므로 변비에 대한 예방약도 처방한다. 술 후 항생제의 사용은 대체적으로 3세대 세팔로스 포린 혹은 페니실린 계열의 항생제를 이용하게 되는데 이는 이 차적인 뇌수막염으로 인한 뇌압상승을 예방한다는 차원에서 술 후 사용이 권장된다. 신경외과에서 선호하는 요추 배액의 경우 뇌척수액 유출로 인해 이미 뇌척수액의 양이 적어진 상태 로 술 후 뇌척수액 유출을 줄이는 데 유의한 차이를 보이지 못 하며 환자의 거동을 제한함으로써 발생하는 이차적인 합병증 으로 혈전색전이나 폐 합병증의 가능성이 있으므로 무조건적 인 사용은 자제하도록 권장하고 있다. ${ }^{6}$

또한 환자로 하여금 비강 내 세척을 지속적으로 시행하도록 하여야 하며 외래에서 지속적인 비강 내 처치를 요하게 되는데 특히 피판 주변부에 위치하는 비강 내 딱지들의 제거가 가장 중 요할 수 있겠다. 그 이유는 딱지가 피판의 재혈관형성을 방해 할 수 있기 때문이다. 실리콘시트는 점막이 재형성 될 2 4주 사 이에 제거하게 된다.

\section{합병증}

비중격 피판의 실패로 인해 뇌척수액 유출이 발생하는 제일 많은 원인은 결손에 비해 피판이 지나치게 작은 경우이다.11) 이 는 피판을 충분히 크게 얻고 접형동 바닥이나 사대오목(clival recess)에 지방 등을 채워 결손부위에 더 잘 안착하게 함으로 써 줄일 수 있다. 또한 수두증(hydrocephalus)과 비만 등이 뇌 척수액 압력을 높이는 원인이 될 수 있으므로 주의한다. 비중 격 자체에 생길 수 있는 합병증으로는 지속적인 딱지 생성이 나 비중격천공이 생길 수 있다. de Almeida 등'2)의 보고에 따 르면 비중격이 재점막화되기까지 89일 정도 걸린다고 하였는 데 이는 비중격 피판을 이용하지 않은 두개저 수술군과 차이
가 없어서 딱지는 비중격 피판자체보다는 수술 중 기구에 의 해 점막이 쉴 새 없이 손상되기 때문으로 생각된다. Kimple 등 3$)$ 은 중비갑개점막을 유리이식으로 사용하여 딱지를 줄일 수 있 다고 하였다. 또 다른 합병증으로 점액낭종을 들 수 있는데 전 통적으로 이 합병증을 줄이기 위해서 충분히 주위 점막을 제 거하는 것이 필요하다고 한다. 하지만 Bleier 등 ${ }^{14}$ 은 점막을 벗 겨서 제거하지 않은 환자군에서 단지 $3.6 \%$ 에서만 그것도 비교 적 초기에 점액낭종이 생기기 때문에 간단히 외래 처치가 가능 해서 어느 정도의 점막 중복(mucosal overlapping)은 큰 문제 되지 않을 것으로 보고하였다. 피판이 너무 좁은 경우에는 가 장자리에 지방으로 덮어주고 그 아래쪽에 근막이식편을 피판 보다 넓게 받쳐준다.

\section{결 론}

문헌들을 통해 살펴본 것처럼 비중격 피판을 이용한 여러 겹 재건은 비교적 낮은 합병증과 실패율을 가지고 있어 첫 번째 선택하여 사용할 수 있는 두개저 재건의 방법이다. 적절한 재 건을 위해서는 두개저 결손의 적절한 평가와 더불어 피판 디 자인, 수술 후 관리까지 유기적으로 이루어져야 한다. 신경외 과와 역할분담, 수가 등 많은 어려움으로 현실적인 제약이 크 지만 내시경과 비중격 피판에 익숙한 이비인후과의사의 보다 적극적인 참여만이 이런 문제들을 바로잡을 수 있고 환자들 에게 보다 유익하리라 생각된다.

\section{REFERENCES}

1) Hadad G, Bassagasteguy L, Carrau RL, Mataza JC, Kassam A, Snyderman $\mathrm{CH}$, et al. A novel reconstructive technique after endoscopic expanded endonasal approaches: vascular pedicle nasoseptal flap. Laryngoscope 2006;116(10):1882-6.

2) Hirsch O. Successful closure of cere brospinal fluid rhinorrhea by endonasal surgery. AMA Arch Otolaryngol 1952;56(1):1-12.

3) Hegazy HM, Carrau RL, Snyderman CH, Kassam A, Zweig J. Transnasal endoscopic repair of cerebrospinal fluid rhinorrhea: a meta-analysis. Laryngoscope 2000;110(7):1166-72.

4) Zweig JL, Carrau RL, Celin SE, Schaitkin BM, Pollice PA, Snyderman $\mathrm{CH}$, et al. Endoscopic repair of cerebrospinal fluid leaks to the sinonasal tract: predictors of success. Otolaryngol Head Neck Surg 2000;123(3):195-201.

5) Soudry E, Turner JH, Nayak JV, Hwang PH. Endoscopic reconstruction of surgically created skull base defects: a systematic review. Otolaryngol Head Neck Surg 2014;150(5):730-8.

6) Liu JK, Schmidt RF, Choudhry OJ, Shukla PA, Eloy JA. Surgical nuances for nasoseptal flap reconstruction of cranial base defects with high-flow cerebrospinal fluid leaks after endoscopic skull base surgery. Neurosurg Focus 2012;32(6):E7.

7) Eloy JA, Choudhry OJ, Friedel ME, Kuperan AB, Liu JK. Endoscopic nasoseptal flap repair of skull base defects: is addition of a dural sealant necessary? Otolaryngol Head Neck Surg 2012;147(1):161-6.

8) Zanation AM, Carrau RL, Snyderman CH, Germanwala AV, Gardner PA, Prevedello DM, et al. Nasoseptal flap reconstruction of high flow intraoperative cerebral spinal fluid leaks during endoscopic skull 
base surgery. Am J Rhinol Allergy 2009;23(5):518-21.

9) Bhatki AM, Pant H, Snyderman CH, Carrau RL, Kassam AB, Prevedello $\mathrm{DM}$, et al. Reconstruction of the cranial base after endonasal skull base surgery: local tissue flaps. Oper Tech Otolaryngol Head Neck Surg 2010;21(1):74-82.

10) Liu JK, Christiano LD, Patel SK, Eloy JA. Surgical nuances for removal of retrochiasmatic craniopharyngioma via the endoscopic endonasal extended transsphenoidal transplanum transtuberculum approach. Neurosurg Focus 2011;30(4):E14.

11) Pinheiro-Neto CD, Snyderman CH. Nasoseptal flap. Adv Otorhinolaryngol 2013;74:42-55.
12) de Almeida JR, Snyderman CH, Gardner PA, Carrau RL, Vescan AD. Nasal morbidity following endoscopic skull base surgery: a prospective cohort study. Head Neck 2011;33(4):547-51.

13) Kimple AJ, Leight WD, Wheless SA, Zanation AM. Reducing nasal morbidity after skull base reconstruction with the nasoseptal flap: free middle turbinate mucosal grafts. Laryngoscope 2012;122(9): $1920-4$.

14) Bleier BS, Wang EW, Vandergrift WA 3rd, Schlosser RJ. Mucocele rate after endoscopic skull base reconstruction using vascularized pedicled flaps. Am J Rhinol Allergy 2011;25(3):186-7. 